\title{
USIA ANAK DAN REMAJA DALAM PERBUATAN PERDATA DAN PIDANA MENURUT HUKUM ISLAM DAN HUKUM POSITIF
}

\author{
Nurwahidah \\ Dosen Fakultas Syariah dan Ekonomi Islam UIN Antasari Banjarmasin \\ E-mail: nurwahidah@uin-antasari.ac.id
}

\begin{abstract}
This paper describes the actions of civil and criminal committed by children or adolescents under the age of 18 years. The issues discussed are how the theories of Islamic Law and Positive Law about the punishment imposed on children or adolescents who commit a civil or criminal act containing legal consequences, and how the views of Islamic Law and Positive Law against some civil and criminal cases involving children or adolescents as the culprit. Based on the results of the study can be concluded, when children or adolescents do civil acts, especially underage marriages in two cases studied, then according to Islamic law the law is valid if it meets harmonious and conditions and age men or women have baligh. But according to the Positive Law the marriage is unlawful if the age of one or both partners is under 16 years for women and 19 years for men. When a child or teenager commits a criminal offense, in four cases examined, according to Islamic Law may be subject to the punishment of ta'zir, and according to the Positive Law shall be punished with minus one third of the principal verdict or returned to the parent or fostered in a government-private.
\end{abstract}

Keywords: child, civil, criminal

Abstrak: Tulisan ini memaparkan tentang perbuatan perdata dan pidana yang dilakukan oleh anak atau remaja yang berusia di bawah 18 tahun. Permasalahan yang dibahas adalah bagaimana teori Hukum Islam dan Hukum Positif tentang hukuman yang dijatuhkan kepada anak atau remaja yang melakukan sesuatu perbuatan perdata atau pidana yang mengandung konsekuensi hukum, dan bagaimana pandangan Hukum Islam dan Hukum Positif terhadap beberapa kasus perdata dan pidana yang melibatkan anak atau remaja sebagai pelakunya. Berdasarkan hasil kajian dapat disimpulkan, ketika anak atau remaja melakukan perbuatan perdata, khususnya perkawinan di bawah umur pada dua kasus yang dikaji, maka menurut Hukum Islam hukumnya sah jika sudah memenuhi rukun dan syaratnya dan usia pria atau wanitanya sudah baligh. Namun menurut Hukum Positif perkawinan tersebut melanggar hukum jika usia salah satu atau kedua pasangan di bawah 16 tahun bagi wanita dan 19 tahun bagi pria. Ketika anak atau remaja melakukan perbuatan pidana, dalam empat kasus yang dikaji, maka menurut Hukum Islam dapat dikenakan hukuman ta'zir, dan menurut Hukum Positif dikenakan hukuman dengan dikurangi sepertiga dari vonis pokoknya atau dikembalikan kepada orang tua atau dibina di suatu lembaga milik pemerintah atau swasta.

Kata kunci: anak, perdata, pidana

\section{Pendahuluan}

Tidak semua anak dan remaja memiliki perkembangan fisk dan mental yang sehat dan mengalami kehidupan yang bahagia dalam keluarganya. Ada kalanya mereka mengalami masalah, baik berkaitan dengan mental, ekonomi maupun sosial dalam keluarga dan lingkungannya. Kondisi ini seringkali berakibat anak melakukan perbuatan perdata atau pidana yang 
mengandung konsekuensi hukum. Di antara perkara perdata yang berkaitan dengan anak dan remaja adalah perkawinan usia muda atau kawin di bawah umur. Sedangkan perkara pidana yang mungkin juga dilakukan anak seperti pencurian, terlibat dalam penyalahgunaan narkoba dan pelanggaran moral kesusilaan.

Dalam tulisan ini dibahas secara kasuistik beberapa perkara perdata terkait dengan perkawinan anak di bawah umur serta perkara pidana yang juga dilakukan oleh anak di bawah umur. Bahasan ini didahului dengan tinjauan teoritis dilanjutkan dengan paparan data lapangan atau yang diperoleh melalui media, kemudian dibahas menurut Hukum Islam dan Hukum Positif.

\section{Interval Usia Yang Dilalui Manusia}

Para ahli membagi periode perkembangan manusia dalam beberapa sudut tinjauannya. Kretschmer membagi periode kehidupan manusia dari lahir hingga dewasa lebih dari sisi kondisi fisiknya yang dibagi dalam empat periode yaitu: Umur 0-3 tahun, seorang anak kelihatan pendek gemuk; Umur 3-7 tahun, seorang anak kelihatan langsing; Umur 7-13 tahun, seorang anak kembali kelihatan pendek gemuk; Umur 13-20 tahun, tubuh anak kelihatan langsing kembali. ${ }^{1}$

Elizabeth B. Hurlock membaginya sejak lahir hingga meninggal dunia dalam klasifikasi umur tertentu. Semuanya dalam 11 periode, yaitu: Masa prenatal, yaitu saat terjadinya konsepsi (pembuahan dalam kandungan) hingga lahir; Masa neonatus, mulai lahir sampai minggu kedua; Masa bayi, akhir minggu kedua sampai akhir tahun kedua; Masa kanak-kanak awal, umur 2 tahun sampai 6 tahun; Masa kanak-kanak akhir, umur 6 tahun sampai 10/11 tahun; Masa pubertas/preadolescence, umur 10/11 sampai 13/14 tahun; Masa remaja awal, umur 13/14 sampai 17 tahun; Masa remaja akhir, umur 17 sampai 21 tahun; Masa dewasa awal, umur 21 sampai 40 tahun; Masa setengah baya, umur 40 sampai 60 tahun; Masa tua umur 60 tahun sampai meninggal dunia. ${ }^{2}$

Menurut Maria Montessori, dalam periodisasi perkembangan manusia terjadi perubahan psikologisnya dalam menghadapi dunia luar sebagai berikut: Umur 0-7 tahun adalah periode penangkapan dan pengenalan dunia luar melalui alat pancaindra; Umur 7-12 tahun adalah periode abstrak, anak-anak mulai mampu menilai perbuatan manusia atas dasar

\footnotetext{
'Imam Bawani, Pengantar Ilmu Jiwa Perkembangan, (Surabaya: Bina Ilmu, 1985), h.132-3.

2Ibid., h. 133.
} 
konsepsi baik dan buruk, dengan kata lain ia telah mampu mengabstrakkan nilai-nilai kehidupan; Umur 12-18 tahun, adalah periode penemuan diri dan kepekaan masa sosial, saat seoranga ank telah menyadari keberadaannya di tengah masyarakat; Umur 18 tahun ke atas adalah periode pendidikan tinggi, saat seseorang telah matang memasuki alam kehidupan sebagai orang dewasa. $^{3}$

Sejalan dengan perkembangan psikologis demikian, terjadi pula periodisasi didaktis (pendidikan). Menurut Johan Amos Comenius, umur 0-6 tahun adalah masa scola materna (sekolah ibu). Umur 6-12 tahun adalah masa scola vermacula, sekolah yang memakai pengantar bahasa ibu; Umur 12-18 tahun, masa scola Latina, sekolah yang memakai bahasa Latin, dan umur 18-24 tahun masa academia, saat seseorang memasuki Perguruan Tinggi. Menurut JJ Rosseau, umur 0-2 tahun disebut masa asuhan, umur 2-12 tahun masa pendidikan jasmani dan latihan pancaindra, dan umur 12-20 tahun masa pembentukan watak dan pendidikan agama. ${ }^{4}$

Menurut Muhammad Said, usia manusia dapat pula dibagi menurut tinjauan biologis dan budaya (fungsional). Secara biologis, usia anak-anak berada 1-12 tahun, usia remaja 12-15 tahun, usia pemuda 15-30

${ }^{3}$ Ibid., h. 135

${ }^{4}$ Ibid., h. 137. tahun dan usia dewasa 30 tahun ke atas. Sedangkan secara budaya (fungsional), usia anak berada di usia 0-12 tahun, remaja 1318/21 tahun dan usia dewasa 18-21 tahun

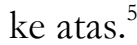

Jadi pada dasarnya para ahli tidak satu pendapat dalam menyebutkan masa yang dilalui manusia dalam periode-periode tertentu. Termasuk dalam hal manusia yang dikategorikan dewasa, ada yang mengatakan di usia 18/21 tahun ke atas, 20 tahun ke atas 30 tahun ke atas, dan sebagainya. Oleh karena itu manusia dewasa tidak dapat dipastikan pada usia tertentu, tetapi paling tidak dengan pedoman usia 20, 25 atau 30 tahun sudah dapat dikatakan dewasa. Sebab secara fisik (biologis), pertumbuhan manusia sudah sempurna.

Kemudian ketika ada di antara anak atau remaja melakukan tindak pidana, maka perlakuannya pun tidak sama dibandingkan dengan jika tindak pidana tersebut dilakukan oleh orang dewasa. Ada pendapat yang mengatakan hukuman tidak berlaku baginya, tetapi ada pendapat jumlah hukumannya dikurangi dan sebagainya. ${ }^{6}$

\section{Batas-Batas Usia dalam Perbuatan Hukum}

5Muhammad Said, Ilmu Pendidikan, (Bandung: Alumni, 1985), h. 171.

6 Anwar Hafidzi, "Prasyarat Poligami Dalam Kitab Fiqih Islam Dan Kompilasi Hukum Islam Perspektif Maslahah Mursalah," Al-Daulah: Jurnal Hukum Dan Perundangan Islam 7, no. 2 (2018): 366-392. 


\section{Batas Usia Baligh}

Usia baligh menjadi ukuran agar kepada yang bersangkutan dapat diberikan status mukallaf, sehingga yang bersangkutan dikenakan kewajiban agama. Menurut Mardaham al-Imam, seseorang dikatakan baligh apabila sudah keluar sperma bagi anak laki-laki dan kedatangan haid (menstruasi) pertama (menarche) bagi anak perempuan. Apabila tidak ada sperma dan haid maka batas usia maksimal untuk bisa dikatakan baligh adalah usia 15 tahun..

\section{Batas Usia Perkawinan}

Dalam hukum Islam menikah (kawin) sangat dianjurkan kepada para pemuda. Sebuah hadits riwayat Imam alBukhari diterangkan;

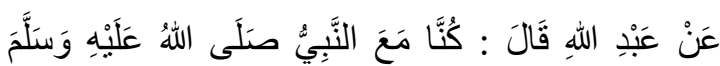

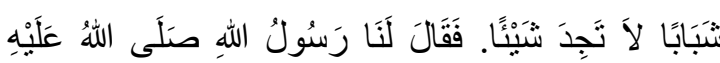

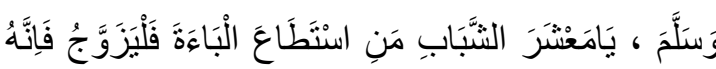

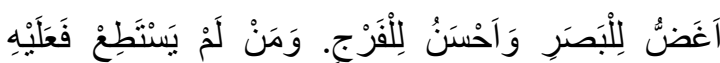

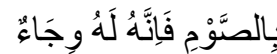

Artinya: Dari Abdillah bin Mas'ud Ra. berkata: di zaman Nabi Saw, kami adalah para pemuda yang tidak memiliki apa-apa. Rasulullah Saw bersabda kepada kami; hai para pemuda, barangsiapa diantara kamu mampu kawin maka kawinlah, karena kawin itu melindungi pandangan mata dan

${ }^{7}$ Mardham al-Imam, Agama Yang Lurus Benar, (Jakarta: Kalam Mulia, 1999), h. 11.

${ }^{8}$ Al-Imam Abi Abdillah Muhammad bin Ismail bin Ibrahim al-Bukhari, Shahih al-Bukhari, Jilid III Juz 6, (Beirut; Dar al-Fikr, 1401 H), h. 117. dan memelihara kehormatan. Tetapi siapa yang tidak mampu kawin maka berpuasalah, karena puasa itu tameng baginya (HR alBukhari).

Hukum Islam tidak menyebutkan berapa batas usia orang yang dinamakan alsyabab (pemuda) tersebut. Namun ukurannya disegi kemampuan dia (al-ba-ab) untuk berumah tangga atau melangsungkan pernikahan/perkawinan. Menurut sebagian ulama, dinamakan al-ba-ah adalah pemuda yang sudah sanggup/mampu bersetubuh, dan mampu pula di segi ekonomi untuk membiayai pernikahan. ${ }^{9}$

Mengingat relativitas tersebut maka di Indonesia pemerintah mengatur kemampuan tersebut pada usia tertentu. UU Nomor 1 tahun 1974 tentang Perkawinan, Pasal 7 ayat (1) menyatakan, perkawinan hanya diizinkan jika pihak pria sudah berusia mencapai 19 tahun dan pihak wanita sudah mencapai usia 16 tahun. Ayat (2) menyatakan, dalam hal penyimpangan terhadap ayat (1) pasal ini dapat meminta dipensasi kepada pengadilan atau pejabat lain yang ditunjuk oleh kedua orang tua pihak pria maupun pihak wanita. Namun pasal 6 tentang syarat perkawinan, ayat (2) menyatakan, untuk melangsungkan perkawinan seorang yang belum berusia 21 tahun harus mendapat izin kedua orang tua. Ketentuan yang sama juga diatur dalam

${ }^{9}$ Al-Imam Muhammad Ismail al-Kahlani al-Shan'ani, Subul al-Salam, (Beirut; Dar al-Fikr, 1411 H), Jilid 2, Juz 3, h. 109. 
pasal 15 ayat (1) dan (2) kompilasi Hukum Islam (KHI).

Melalui berbagai pertimbangan, Menteri Dalam Negeri mengeluarkan Surat Keputusan Nomor 27 tahun 1983 tentang Usia Perkawinan yang menganjurkan agar perkawinan dilaksanakan pada usia 20 tahun bagi wanita dan 25 tahun bagi pria. Upaya ini dimaksudkan untuk lebih memberikan perhatian kepada wanita pada usia muda agar dapat lebih mengembangkan diri dan dapat mengikuti pendidikan pada jenjang yang lebih tinggi dan pihak pria lebih siap secara mental, ekonomi dan sosial. ${ }^{10}$

\section{Batas Usia Pemberlakuan Hukum}

Pidana

Tindak pidana dalam berbagai bentuknya ada kalanya juga dilakukan oleh anak dan remaja. Dalam hal ini Hukum Islam dan Hukum Positif Indonesia yaitu Kitab Undang-undang Hukum Pidana (KUHP) mengaturnya secara berbeda dibandingkan hukuman untuk tindak pidana yang dilakukan oleh orang dewasa.

\section{Hukum Islam}

\footnotetext{
${ }^{10}$ Majelis Ulama Indonesia (MUI), Ajaran Islam dan Penanggulangan Perkawinan Usia Muda, (Jakarta: MUI dan UNICEF, 1991), h. 59. Anwar Hafidzi, "Dampak Dari Penetapan UU Nomor 26 Tahun 2000 Terhadap Kejahatan Kemanusiaan Dan Genosida Di Indonesia," Syariah Jurnal Hukum Dan Pemikiran 15, no. 2 (2016).
}

Dalam sebuah hadits disebutkan bahwa hukum itu tidak diberlakukan atas tiga golongan, yaitu anak kecil hingga ia dewasa (baligh), orang yang tidak berakal (gila) dan orang yang tidur hingga ia bangun. Berangkat dari sini maka kedewasaan dan keberakalan seseorang menjadi batas untuk memberlakukan hukum syariat kepadanya. Ukuran baligh sudah disebutkan terdahulu yaitu keluar sperma (laki-laki) dan haid (perempuan) atau maksimal berusia 15 tahun. Adapun tentang kenormalan berpikir untuk bisa atau tidak bisa dikenakan hukum syari at diterangkan sebagai berikut:

a. Masa tidak adanya kemampuan berpikir Masa ini dimulai sejak dilahirkan sampai usia tujuh tahun dengan kesepakatan para fuqaha. Masa ini disebut masa anak belum tamyiz, yaitu belum bisa membedakan suatu perbuatan baik dan buruk. Kemampuan berpikir anak memang tidak sama, ada yang cepat ada yang lambat, maka usia tujuh tahun menjadi batas supaya mudah dalam menentukan hukuman. Karena itu perbuatan jarimah (tindak pidana, kejahatan) yang dilakukan oleh anak yang berusia di bawah tujuh tahun, tidak dijatuhi hukuman, baik berupa hukuman pidana (hadd) maupun pengajaran (ta'zir). Tetapi kepada anak itu dibebani kewajiban perdata, yang dibebankan kepada 
harta milik pribadi (orangtuanya) dengan mengganti kerugian yang diderita oleh orang lain.

\section{b. Masa kemampuan berpikir lemah}

Masa ini dimulai sejak anak berusia tujuh tahun sampai mencapai kedewasaan (baligh), dan kebanyakan fuqaha membatasinya pada usia 15 tahun. Kalau seorang anak telah mencapai usia 15 tahun maka ia sudah dianggap dewasa, meskipun boleh jadi belum dewasa dalam arti sebenarnya. Namun usia ini menurut Abu Hanifah dibatasi pada usia 18 tahun dan ada riwayat 19 tahun dan di kalangan mazhab Maliki juga sama dengan pendapat Abu Hanifah ini.

Pada usia di atas anak yang melakukan tindak pidana tidak dikenai pertanggungjawaban pidana (hadd), tetapi dikenakan pengajaran (ta'zir). Meskipun pengajaran itu hakikatnya juga berupa hukuman, tetapi tetap dianggap sebagai pengajaran saja. Meskipun anak itu misalnya berkali-kali melakukan kejahatan dan berkali-kali pula dikenakan pengajaran, maka ia tetap tidak bisa dianggap sebagai pengulang kejahatan (residivist).

c. Masa kemampuan bepikir penuh \

Usia ini dimulai sejak seorang anak mencapai usia kecerdasan (sinn al-rusyd), atau dengan perkataan lain, setelah mencapai usia 15 tahun atau 18 tahun menurut pendapat di kalangan fuqaha. Pada masa ini seseorang dikenakan pertanggungjawaban pidana atas kejahatankejahatan yang diperbuatnya bagaimana pun macamnya. ${ }^{11}$

Hukum pidana positif yang berlaku di beberapa negara tidak sama dalam menentukan batas usia tersebut. Inggris dan india membatasi pada usia tujuh tahun, dan batasan ini sama dengan yang berlaku pada masa Kekaisaran Romawi sebelum datangnya agama Islam. Sementara di Italia dibatasi pada usia sembilan tahun. Ada versi mengatakan batas usia penjatuhan hukuman pidana di Republik Persatuan Arab (RPA) khususnya Mesir dan Syria 15 tahun, India dan Sudan 12 tahun, Inggris 14 tahun dan Perancis 16 tahun. Jadi batasan usia pada masing-masing negara tidak sama. ${ }^{12}$

\section{Hukum Positif}

Di Indonesia tindak pidana yang dilakukan oleh anak-anak di segi hukum acaranya diatur dalam UU Nomor 3 tahun 1997 tentang Pengadilan Anak (UU Pengadilan Anak). Pasal 1 ayat (1) dan pasal 4 ayat (1) menyatakan bahwa anak yang melakukan tindak pidana disebut dengan Anak Nakal, yaitu mereka yang berusia 8

\footnotetext{
${ }^{11}$ Ahmad Hanafi, Asas-asas Hukum Pidana Islam, (Jakarta: Bulan Bintang, 1986), h. 369-370.

${ }^{12}$ Ibid., h. 370-371.
} 
tahun tetapi belum sampai berumur 18 tahun dan belum pernah kawin. Anak tersebut jika melakukan tindak pidana, maka persidangan yang dilakukan terhadapnya adalah secara khusus dan disebut dengan Sidang Anak, dan pasal 8 ayat (2) mengatur bahwa Sidang Anak dilakukan secara tertutup. ${ }^{13}$

Undang-Undang Pengadilan Anak ini dalam pasal-pasalnya menganut beberapa asas yang membedakannya dengan sidang pidana untuk orang dewasa. Adapun asasasas itu adalah sebagai berikut: Dalam proses persidangannya ditangani pejabat khusus, yaitu di tingkat penyidikan oleh penyidik anak, di tingkat penuntutan oleh penuntut umum, dan di pengadilan oleh hakim anak, hakim banding anak, \& hakim kasasi anak (pasal 1 ayat 5, 6, dan 7). Kemudian dalam proses pembinaannya, mengakui peran pembimbing kemasyarakatan Pekerja Sosial dan Pekerja Sosial Sukarela (pasal 1 ayat 11). ${ }^{14}$

Adapun bentuk hukumannya diatur dalam Pasal 45 KUHP sebagai berikut;

Jika seorang yang belum dewasa dituntut karena perbuatan yang dikerjakannya ketika umurnya belum 16 tahun, hakim boleh memerintahkan, supaya sitersalah itu dikenbalikan kepada orang tuanya; walinya atau pemeliharanya, dengan

${ }^{13}$ Undang-Undang Peradilan Anak, (Jakarta: Sinar Grafika, 2000), h. 4-5.

${ }^{14}$ Ibid. tidak dikenakan sesuatu hukuman; atau memerintahkan supaya sitersalah diserahkan kepada pemerintah dengan tidak dikenakan sesuatu hukuman, yakni jika perbuatan itu masuk bagian kejahatan atau salah satu pelanggaran yang diterangkan dalam pasal 489, 490, 492, 496, 497, 503, 504, 505 514, 417, 519, 526, 531, 532, 536 dan 540, dan perbuatan itu dilakukannya sebelum lalu dua tahun sesudah keputusan dahulu yang menyalahkan dia melakukan salah satu pelanggaran ini atau suatu kejahatan; atau menghukum anak yang bersalah itu.

Berkenaan dengan ketentuan pasal di atas, R Soesilo menerangkan bahwa pasal ini menuntut dipenuhinya dua syarat, yang kedua-duanya harus dipenuhi, yaitu:

1. orang itu waktu dituntut harus belum dewasa. Yang dimaksud dengan belum dewasa ialah mereka yang belum berusia 21 tahun dan belum kawin. Jika orangnya sudah kawin dan bercerai sebelum umur 21 tahun, ia tetap dipandang dewasa.

2. tuntutan itu mengenai peristiwa pidana yang telah dilakukan orang tersebut pada waktu sebelum berumur 16 tahun.

Jika kedua syarat di atas terpenuhi maka hakim dapat memutuskan salah satu dari tiga kemungkinan, yaitu:

1. anak itu dikembalikan kepada orang tua atau walinya, dengan tidak diatuhi hukuman suatu apa; 
2. anak itu dijadikan anak Negara, maksudnya tidak dijatuhi hukuman, akan tetap diserahkan kepada Rumah Pendidikan Anak-anak nakal, untuk mendapat didikan dari Negara sampai anak itu berumur 18 tahun. Hal ini hanya dapat dilakukan bila anak itu telah berbuat suatu kejahatan atau pelanggaran yang termaktub dalam pasal ini dan sebagai residive.

3. anak itu dijatuhi hukuman seperti biasa. Dalam hal ini ancaman hukuman dikurangi sepertiganya.

Mengacu kepada beberapa peraturan di atas, tampaklah bahwa hakim diberikan kesempatan untuk menimbang tentang kecakapan rohaninya terdakwa yang masih muda itu. Apabila misalnya hakim berpendapat bahwa anak-anak yang umurnya 9 tahun atau 13 tahun kecakapan akalnya ternyata tidak normal berkembangnya, maka sudah cukup hakim mengirimkan kembali anak-anak itu kepada orang tuanya, wali atau orang yang memeliharanya, dengan tidak dijatuhi suatu hukuman. Akan tetapi apabila menganggap anak yang berumur 13 atau 15 tahun telah berbuat suatu kejahatan dengan akal yang cukup mampu membeda-bedakan, hakim ada kesempatan pula untuk menjatuhkan hukuman, akan tetapi hukuman yang dijatuhkan itu tidak boleh lebih dari dua pertiga maksimum hukuman yang diancamkan. ${ }^{15}$

$$
\text { Selanjutnya pasal } 46 \text { ayat }
$$
menerangkan bahwa jika hakim memerintahkan supaya sitersalah diserahkan kepada pemerintah, maka ia baiknya ditempatkan di rumah pendidikan negeri, supaya di situ atau kemudian dengan cara lain, ia mendapat pendidikan dari pihak pemerintah, baik diserahkan kepada orangorang yang ada di Negara Indonesia atau kepada perserikatan yang mempunyai hak badan hukum (rechtspersoon) yang ada di Negara Indonesia atau kepada balai derma yang ada di Negara Indonesia supaya di situ mendapat pendidikan dari mereka, atau kemudian dengan cara lain dari pemerintah, dalam kedua itu selama-lamanya sampai cukup berusia 18 tahun.

Berdasarkan keentuan dalam pasal di atas tampak bahwa pelaku tindak pidana yang masuk kategori belum dewasa, di bawah 18 tahun, maka sesuai dengan putusan hakim ia dapat diserahkan kembali kepada orang tuanya, diserahkan kepada suatu lembaga Negara atau milik swasta untuk dididik dan dapat pula dimasukkan ke penjara dengan vonis hukuman tiga perempat dari ancaman pidana pokoknya

${ }^{15 R}$. Soesilo, Kitab Undang-undang Hukum Pidana serta Komentar-koemntarnya Lengkap Pasal Demi Pasal, (Bogor: Politeia, 1991), h. 62. 
atau dikurangi seperempat dari ancaman pidana pokoknya.

\section{Beberapa Kasus Perbuatan Hukum}

\section{Terkait Usia}

\section{A. Kasus Perkawinan}

Kasus-kasus perkawinan sangat banyak terjadi terkait dengan batas usia ini, maka pria atau wanitanya dianggap belum sampai pada usia yang dibolehkan untuk kawin, aatu diistilahkan dengan perkawinan di bawah umur atau pernikahan dini. Diantara kasus-kasus tersebut adalah:

\section{Perkawinan Syekh Puji}

Di antara kasus yang sempat menimbulkan heboh beberapa tahun yang lalu adalah perkawinan Syekh Puji dengan anak wanita yang dianggap masih di bawah umur. Antara News Semarang 22 Desember 2008 memberitakan bahwa Pujiono Cahyo Widianto, yang lebih dikenal sebagai Syekh Puji, warga Desa Bedono, Kecamatan Jambu, Kabupaten Semarang menimbulkan heboh dalam berita-berita media nasional, karena menikahi anak di bawah umur. Pujiono yang berusia 43 tahun menikahi Lutfiana Ulfa (12 tahun), anak yang baru lulus dari sekolah dasar (SD) pada 8 Agustus 2008, secara agama sebagai istri keduanya. Pujiono yang memiliki Pondok Pesantren Miftahul Jannah putra-putri, dikenal sebagai pengusaha sukses yang dermawan. Setiap tahunnya ia selalu membagi-bagikan zakat. Bahkan Ramadan 2008, Pujiono membagikan zakat sebanyak Rp1,3 miliar.

Pernikahan Syekh Puji dengan istri keduanya yang masih bocah itu memunculkan pro dan kontra masyarakat. Sebagian pihak menilai bahwa pernikahan yang dilakukan oleh laki-laki dan perempuan yang sudah baligh dan memenuhi syarat-syarat pernikahan, sah menurut hukum Islam. Namun, di pihak lain Syekh Puji dianggap telah melanggar hukum positif UU Perkawinan yang mengatur batas usia menikah untuk anak perempuan adalah 16 tahun. Sikap kontra terhadap pernikahan tersebut disampaikan oleh banyak pihak mulai dari Komisi Perlindungan Anak Indonesia (KPAI), Menteri Agama, Komisi Nasional (Komnas) Perlindungan Anak, Majelis Ulama Indonesia (MUI), dan sejumlah lembaga swadaya masyarakat (LSM) yang tergabung dalam Jaringan Peduli Perempuan dan Anak (JPPA) Jawa Tengah. Di Kecamatan Gabus Wetan, Kabupaten Indramayu misalnya, di daerah tersebut perempuan rata-rata menikah pada usia 14-15 tahun, sedangkan laki-laki berusia 17-20 tahun. Untuk menutupi status usia yang masih di bawah umur, tidak jarang dari mereka yang memalsukan usia. Di tempat lain seperti di Desa Leggung Barat, Kabupaten Sumenep, menikahkan anak usia dini untuk 
perempuan 13 tahun, lulus SD dan laki-laki 15 tahun atau usia SMP merupakan hal wajar. $^{16}$

Pernikahan usia muda serta pernikahan di bawah umur sebagian besar terjadi karena alasan ekonomi. Banyak orang tua yang terpaksa menikahkan anak perempuannya yang masih di bawah umur agar beban ekonomi keluarga menjadi berkurang, bahkan dengan pernikahan tersebut diharapkan dapat meningkatkan derajat ekonomi keluarga. Ada pula yang menikahkan anak perempuannya yang di bawah umur karena alasan tradisi. Sebab itu pula yang menjadi dasar dari pernikahan Syekh Puji dengan Ulfa. Pernikahan tersebut telah mengangkat status ekonomi anak pasangan Suroso (35) dan Siti Hurairah (33). Tak hanya itu saja, Ulfa pun mendapat didikan demi kemajuan dirinya dan masa depan perusahaan suaminya. Situasi tersebut tentu akan berubah, saat ada tuntutan dari pihak luar seperti dari Komnas Perlindungan Anak yang meminta agar dilakukan pembatalan pernikahan dan berharap agar kedua orang tua Ulfa bersedia menerimanya dan memenuhi hak si anak untuk berkembang. Tuntutan pembatalan pernikahan didasarkan pada alasan agar Ulfa dapat merasakan masa anak-anak dan meneruskan sekolahnya. Bukan hanya

16Aditia Maruli Radja, "Heboh Kasus Syekh Puji", Antara News, Semarang 22 Desember 2008. tuntutan pembatalan pernikahan, Syekh Puji bahkan telah dilaporkan ke Polwiltabes Semarang dengan alasan yang bersangkutan telah melanggar UU Perlindungan Anak.

$$
\text { Ada penilaian pembatalan }
$$

pernikahan tersebut dapat menyelamatkan si anak untuk kembali ke dunianya. Namun sayangnya, banyak pihak tersebut melupakan bahwa si anak adalah juga subyek yang perlu dipertimbangkan pendapatnya.

Dalam konteks ini, masyarakat harus bijak dan tidak melulu menempatkan Ulfa dan anak perempuan lainnya yang dinikahkan di bawah umur hanya sebagai obyek belaka. Ulfa dan yang lainnya adalah manusia yang memiliki hak atas diri dan masa depannya yang harus diposisikan sebagai subyek yang patut ditanyakan pendapat dan keinginannya. ${ }^{17}$

Melihat kasus Syekh Puji di atas, maka berdasarkan hukum Islam perkawinannya dianggap sah, sebab sudah memenuhi syarat perkawinan. Mempelai perempuan walaupun dianggap masih sangat muda (12 tahun), namun dapat dikatakan sudah baligh, terbukti yang bersangkutan bisa hamil, tidak lama setelah pernikahan berlangsung. Hal ini sejalan pula dengan pendapat para ulama mazhab Maliki bahwa darah yang keluar pada anak wanita di usia 9-13 tahun adalah darah haid, begitu

${ }^{17}$ Ibid. 
juga mazhab Hanafi mengatakan wanita di usia 9 tahun sudah bisa mengeluarkan haid hingga usia 55 tahun. ${ }^{18}$

Kasus Syekh Puji ini bertentangan secara administrasi dengan UU Perkawinan yang mengatur batas usia perkawinan, bahwa bagi perempuan disyaratkan usia minimalnya adalah 16 tahun. Namun kasus ini tidak dapat dipidana, kecuali jika wanita yang dinikahi oleh Syekh Puji tersebut atau kasus sejenisnya mengalami luka berat dan atau mati akibat pernikahan atau persetubuhannya. Hal ini diatur pada pasal 288 KUHP ayat (1-3) sebagai berikut: (1) Barangsiapa bersetubuh dengan istrinya yang diketahuinya atau harus patut diksangkanya, bahwa perempuan itu belum masanya untuk berkawin, dihukum penjara selama-lamanya empat tahun, kalau perbuatan itu berakibat perempuan itu luka; (2) Kalau perbuatan itu menyebabkan perempuan luka berat, dijatuhkan hukuman penjara selama-lamanya delapan tahun; (3) Jika perbuatan itu menyebabkan kematian perempuan itu dijatuhkan hukuman penjara selama-laanya 12 tahun. ${ }^{19}$

Pada kasus ini tidak ditemukan istrinya luka, luka berat apalagi mati akibat pernikahannya. Karena itu mestinya perbuatan tersebut tidak dianggap sebagai

${ }^{18}$ Ibrahim Muhammad al-Jamal, Figh al-Mar'ah alShalihah, Alih bahasa Anshari Umar Sitanggal, Fiqih Wanita, (Semarang: Asy-Syifa, 1986), h.46-47.

${ }^{19}$ R. Soesilo, Op. cit., h. 212. perbuatan pidana, hanya pelanggaran biasa, yaitu pelanggaran UU Perkawinan. Kasuskasus serupa juga banyak terjadi di daerah lain, seperti di Jawa Barat, sebagaimana dikemukakan oleh Seto Mulyadi. Bahkan di Provinsi Kalimantan Selatan pun banyak terjadi pernikahan di bawah umur, di mana ditengara daerah ini berada di peringkat 5 pernikahan bawah umur se Indonesia, sehingga pada tanggal 13 Desember 2017, bertempat di Mahligai Pancasila Banjarmasin dicetuskan Gerakan Bersama Setop Perkawinan Anak. ${ }^{20}$

\section{Perkawinan Mohammad Alfin Faiz}

Pernikahan antara Mohammad Alfin Faiz (17 tahun) dengan Laissa Chou (20 tahun)..Putra ulama kondang Mohammad Arifin Ilham ini menikahi wanita Tionghoa yang sudah masuk Islam bersama keluarganya. ${ }^{21}$

Meskipun usia perempuannya sudah 20 tahun dan tidak melanggar ketentuan batas usia dalam UU Perkawinan, namun usia laki-lakinya hanya 17 tahun dan hal ini tidak sesuai dengan peraturan dalam UU Perkawinan yang menentukan batas usia 19 tahun untuk kebolehan lelaki menikah. Namun karena Arifin Ilham menikahkan anaknya secara resmi dan tercatat, maka

${ }^{20}$ 'Perkawinan Usia Dini”, Banjarmasin Post, 16 Desember 2017, h. 6 .

21 idntimes.com "Menikah di usia 17 tahun, bagaimana caranya Alfin Faiz menafkabi isterinya" diakses pada tanggal 20 Agustus 2016. 
yang bersangkutan mengajukan permohonan dispensasi kepada pengadilan, dan hal ini sudah sesuai dengan ketentuan pasal 7 ayat (2).

Adapun pernikahan Mohammad Alfin Faiz, sebagaimana sering dijelaskan oleh Ustadz Arifin ilham dalam ceramahnya, lebih dimaksudkan dalam kerangka dakwah. Pertama, pihak wanitanya adalah muallaf dari keturunan Cina, sehingga tak hanya si wanita, bahkan keluarga besarnya juga masuk Islam. Selain itu Arifin ilham juga ingin menekankan bahwa perkawinan usia muda mengandung banyak maslahat ketika kedua mempelai sudah memiliki kesiapan mental, dan sosial. Pernikahan ini juga tidak bertentangan dengan UU Perkawinan, sebab sudah mendapatkan dispensasi untuk menikah di bawah ketentuan usia yang berlaku.

\section{Kasus Pidana}

Ada berbagai kasus "tindak pidana" yang biasa dilakukan oleh anak-anak atau remaja, berikut dikemukakan beberapa contohnya:

\section{Pencurian minyak rambut}

Belum lama tadi (15 Desember 2017), empat orang anak (berusia 8-12 tahun) dan masih bersekolah SD, mencuri minyak rambut bermerek di sebuah pusat belanja (...Mart) di Kota Banjarmasin.
Mereka berasal dari kawasan salah satu Kelurahan di Kecamatan Banjarmasin Timur. Biasanya mereka membeli minyak rambut di warung dekat lingkungan rumahnya. Namun kali ini mereka nekad mencurinya di sebuah pusat belanja.

Akhirnya, mereka terekam kamera CCTV (Closed Circuit Television) yang ada di pusat belanja tersebut. Salah seorang penjaga toko mengenali satu di antara empat anak tersebut, lalu melakukan tindakan. Tanpa berbelit-belit, anak-anak tersebut pun segera mengaku. Perbuatan ini setelah dilakukan perundingan dengan keluarga anak-anak bersangkutan tidak dilaporkan ke polisi dan pengadilan, tetapi diselesaikan dengan cara damai, ${ }^{22}$ yaitu pihak keluarga mengganti kerugian toko yang ditaksir berjumlah Rp 250.000, yang dibebankan secara proporsional, dalam arti keluarga yang lebih mampu dibebani lebih banyak dibandingkan dengan orang tua yang kurang mampu.

Petugas sekuriti hanya berpesan kepada pihak orang tua agar lebih mendidik anak-anak mereka, lebih berhati-hati dan ikut mengawasi ketika anak tersebut tidak berada di rumah. Sedapat mungkin juga memberikan uang yang cukup sehingga ketika anak memerlukan sesuatu mereka

22 Anwar Hafidzi, "Eksistensi Advokat Sebagai Profesi Terhormat (Officium Nobile) Dalam Sistem Negara Hukum Di Indonesia," Khazanah: Jurnal Studi Islam Dan Humaniora 13, no. 1 (2015). 
dapat membelinya, bukan mencuri di suatu tempat. Sepengetahuan penulis, anak-anak tersebut dimarahi oleh orang tuanya, bahkan ada yang dipukul. Pendekatan yang digunakan ini sudah sesuai dengan teori hukum Islam. Anak-anak tersebut masih dianggap di bawah umur, masih berada dalam taraf kemampuan berpikir yang lemah, jadi tidak perlu dihukum dan dimintai pertanggungjawaban sebagaimana orang dewasa. Pemberian ganti rugi, dan dimarahi atau dipukul oleh orang tuanya sudah dapat dianggap sebagai hukuman atas mereka.

Begitu juga menurut hukum Positif sudah sesuai, yakni anak-anak tersebut tidak dihukum, namun dikembalikan kepada orang tuanya. Hanya saja hukum positif menghendaki untuk tindak pidana anakanak seperti ini mestinya tetap disidang melalui Sidang Anak yang bersifat tertutup, kemudian hakim memutuskan anak tersebut dikembalikan kepada orangtuanya atau dititipkan kepada Lembaga Pemasyarakatan Anak (Lapas) milik negara dengan status sebagai anak nakal, atau lembaga swasta lain seperti pondok pesantren untuk dibina dan dididik sebagaimana mestinya.

\section{Narkoba dan Zenith}

Kasus lainnya dilakukan oleh Y, siswa sebuah SMPN di Kota Banjarmasin yang masih berusia 15 tahun. Tindak pidana yang dilakukannya, yang bersangkutan bersama 20 orang temannya mengkonsumsi salah satu jenis narkoba, dan juga pil zenith, dan sesekali juga menenggak minuman keras. Ketika Badan Narkotika Nasional (BNN) Kota Banjarmasin melakukan penyuluhan lapangan sekaligus melakukan tes urine di sekolah bersangkutan, terjaringlah 20 anak di atas, termasuk Y. Meskipun demikian, pihak BNN tidak memproses para siswa tersebut di kepolisian, dan mempersilakan kepolisian menyelidiki siapa dan dari mana asal narkoba yang digunakan. Namun BNN berusaha melakukan pembinaan. Kepada siswa diminta untuk rutin datang ke kantor BNN untuk diberikan terapi, pemberian nasihat oleh psikater, sambil mengkonsumsi obat yang disediakan selama program 16 minggu.

Setelah menjalani 16 minggu program pengobatan, $\mathrm{Y}$ relatif sembuh, dan sempat melanjutkan sekolahnya ke sebuah SMKN di Kota Banjarmasin. namun karena pengaruh pergaulan, $\mathrm{Y}$ kembali mengonsumsi pil zenith dan tertangkap lagi oleh operasi pihak BNN dan kepolisian. Akhirnya Y diberhentikan dari sekolah dan diserahkan kepada orang tuanya bernama Sy. Pendekatan yang digunakan oleh instansi terkait yaitu BNN pada kasus ini sudah tepat yaitu lebih kepada membina yang bersangkutan, sebab usia sitersalah 
hanya sekitar 15 tahun, dengan dan orang tuanya bercerai, akhirnya mengembalikan kepada orang tuanya, diadukan ke kepolisian dan pengadilan. B kemudian orangtuanya mengirim sianak menjalani sidang tertutup dan dijatuhi pada lembaga yang diharapkan dapat hukuman selama 3 tahun, dengan dikurangi melakukan pembinaan secara intensif sepertiganya, sehingga yang dijalaninya sehingga sianak kembali ke jalan yang benar. hanya 2 tahun dipotong masa tahanan. $\mathrm{B}$ Menurut Kepala BNN Kota Banjarmasin, dititipkan ke Lapas Martapura dan sebelum AKBP H. Mohammad Ilyas, SH., MH, yang sampai usia 18 tahun ia kemudian sangat penting dalam kasus narkoba dan dibebaskan. ${ }^{23}$ turunannya adalah menyadarkan sitersalah (anak) akan bahaya narkoba dan turunannya lalu ada kesadaran sendiri untuk sembuh. Kalau hanya pihak lain yang ingin menyembuhkan, sementara yang bersangkutan tidak memiliki kemauan, maka sulitlah untuk disembuhkan, sehingga akan selalu terulang melakukan hal yang sama.

\section{Pencurian sepeda}

Jauh sebelumnya, seorang mahasiswa Fakultas Dakwah IAIN Antasari melakukan penelitian tentang kegiatan penyuluhan agama di Lembaga Pemasyarakatan Anak (Lapas) Martapura. Di sini ternyata ada sejumlah anak yang menjalani hukuman dan pembinaan akibat tindak pidana yang dilakukannya. Salah satunya bernama $\mathrm{B}$, berusia 15 tahun, asal Banjarmasin. Kejahatan yang dilakukannya adalah mencuri sepeda BMX milik orang lalu. Karena B berasal dari keluarga yang kurang mampu, tidak sanggup mengganti

\section{Kasus Saipul Jamil}

Artis dangdut Saipul Jamil pada ahun 2016 yang lalu juga mengalami masalah hukum. Bekas suami artis Dewi Perssik ini dituduh melakukan pencabulan, hubungan sejenis dengan seorang remaja berinisial $\mathrm{N}$, berusia 17 tahun. Semula Saipul menolak tuduhan tersebut, tetapi kemudian pihak kepolisian berhasil membuktikannya. Belakangan Saipul menyatakan hubungannya tidak dapat dipidana karena berdasarkan suka sama suka, sebab $\mathrm{N}$ sudah tergolong dewasa, tetapi pihak kepolisian dan pengadilan tetap menghukumnya.

Hukuman Saipul Jamil pada kasus pencabulan ini diperberat dari 3 tahun menjadi 5 tahun penjara di tingkat banding yang sebelumnya ditangani PN Jakarta Utara.

23 Darjat, Bimbingan Penyuluhan Agama di Kalangan Narapidana Anak di Lapas Martapura (Skripsi: Fakultas Dakwah IAIN Antasari, Banjarmasin,1997) h. 50 
Menurut Hukum Islam, homoseksual diharamkan, dan pelakunya dikenakan hukuman. Dalam hal ini terbagi dalam tiga pendapat; Pertama, pendapat yang mengatakan bahwa pelaku harus dibunuh secara mutlak. Para sahabat Nabi, Nashir, Qasim bin Ibrahim dan Imam Syafii mengatakan, pelaku homoseksual adalah dibunuh, meskipun pelakunya tersebtu masih perjaka, baik yang mengerjakan maupun yang dikerjai.

Pendapat kedua mengatakan, perbuatannya dikenakan hukumn hadd sebagaimana hadd zina. Jika pelakunya perjaka harus didera dan jika muhshan harus dirajam. Pendapat kedua ini dianut oleh Said bin Musayyab, Atha' bin Abu Rabah, Hasan, Qatadah dan Nakhai, Tsauri, Auzha'i, Abu Thalib, Imam Yahya dan Imam Syafii.

Pendapat ketiga mengatakan pelaku homoseks harus diberi sanksi, sesuai dengan keputusan hakim. Kalangan yang berpendapat demikian adalah Imam Abu Hanifah, Muayyad, Billah, Murtadha, Imam Syafii dalam satu pendapat. Mereka ini berpendapat bahwa homoseks bukan termasuk hakikat zina, sehingga hukuman zina tidak dapat diterapkan untuk menghukum pelaku homoseks. ${ }^{24}$

${ }^{24}$ Sayyid Sabiq, Figh al-Sunnah, Jilid 9, Alih bahasa Mohammad Nabhan Husein, (Bandung: Almaarif, 1987), h. 136.
Hakikat zina adalah memasukkan penis pria ke dalam vagina wanita yang bukan miliknya (istrinya) dan tidak ada unsur syubhat, kekeliruan atau keserupaan. Sedangkan homoseksual dilakukan dengan cara memasukkan penis (zakar) pria ke dalam anus (dubur) pria lainnya. Karena itu kalangan ulama seperti Abu Hanifah berpendapat bahwa hukuman atas pelakunya adalah ta'zir dengan tujuan untuk mendidik, sedangkan jenis ta'zirnya diserahkan kepada putusan hakim. ${ }^{25}$

Melihat hukuman yang dijatuhkan oleh hakim kepada Saipul Jamil, dapat dikatakan sudah sesuai dengan hukum Islam, khususnya pendapat ketiga. Namun mestinya hukuman itu dapat juga dikenakan kepada pasangannya, baik yang mengerjai maupun dikerjai, karena hakikatnya mereka sama-sama melakukan. Usia 17 tahun menurut Hukum Islam sudah dapat dikenakan sanksi hukum.

Menurut pasal 292 KUHP, orang dewasa yang melakukan perbuatan cabul dengan orang belum dewasa dari jenis kelamin yang sama, sedang diketahuinya atau patut harus disangkanya hal belum dewasa itu, dihukum penjara selamalamanya lima tahun. Mengacu kepada

\footnotetext{
${ }^{25}$ Masyfuk Zuhdi, Masail Fiqhiyah, Jakarta: Haji masagung, 1996), h. 34. Anwar Hafidzi and Safruddin Safruddin, "KONSEP HUKUM TENTANG RADHA'AH DALAM PENENTUAN NASAB," Khazanab: Jurnal Studi Islam Dan Humaniora 13, no. 2 (2017): 283-317.
} 
ketentuan pasal ini maka vonis untuk Saipul Jamil jika benar terbukti melakukan perbuatan yang dituduhkan, maka hal tersebut sudah sesuai dengan hukum Positif. Namun pembebasan dari hukuman untuk pasangannya yang belum berusia 18 tahun, tidak sesuai dengan hukum Positif, seharusnya yang bersangkutan tetap dihukum dengan dikurangi sepertiga dari ancaman pidana pokoknya. Kecuali jika yang bersangkutan terpaksa melakukannya, maka ia bisa dibebaskan dari tuntutan. Dari fakta yang berkembang, tidak ditemukan unsur pemaksaan tersebut.

\section{Penutup}

Berdasarkan paparan di atas dapatlah disimpulkan bahwa anak termasuk golongan manusia yang sudah bisa melakukan sesuatu perbuatan perdata, termasuk juga bisa melakukan tindak pidana dalam berbagai bentuknya. Namun anak tersebut memiliki keterbatasan fisik, akal dan mental, oleh karena itu hukuman yang dijatuhkan kepadanya ketika melakukan tindak pidana berbeda dengan hukuman untuk orang dewasa.

Ketika anak melakukan perbuatan perdata, seperti melangsungkan perkawinan, maka menurut pandangan Hukum Islam, pernikahannya sah, jika sudah baligh dan terpenuhi rukun dan syaratnya, namun secara administratif pernikahannya melanggar ketentuan dalam UU Perkawinan. Ketika melakukan tindak pidana, maka kejahatan (jarimah) yang dilakukan anak tersebut menurut Hukum Islam, dapat dikenakan hukuman ta'zir sesuai keputusan hakim. Menurut Hukum Positif, apabila anak di bawah usia 18 tahun melakukan tindak pidana, maka kepadanya dapat dikenakan hukuman yang dikurangi sepertiga dari vonis pokoknya, atau dikembalikan kepada orangtua atau dididik oleh lembaga Negara atau swasta yang dapat membinanya. Hukum Positif mengatur bahwa anak yang melakukan tindak pidana harus diperlakukan ecara khusus dan terpisah dari tindak pidana dewasa, mulai dari proses penyidikannya, penyidangan, penuntutan hingga pembinaannya di lembaga pemasyarakatan atau tempat lainnya.

\section{DAFTAR PUSTAKA}

Abdurrahman, Kompilasi Hukum Islam di Indonesia, Jakarta: Akademika Pressindo, 1992.

Al-Bukhari, Al-Imam Abi Abdillah Muhammad bin Ismail bin Ibrahim, Shahih al-Bukhari, Jilid III Juz 6, (Beirut; Dar al-Fikr, 1401 H).

Al-Shan'ani, al-Imam Muhammad Ismail alKahlani al-Shan'ani, Subul al-salam, Beirut; Dar al-Fikr, $1411 \mathrm{H}$. 
Atriana, Ariana, "Saipul Jamil Divonis 5

Tahun, DetikNews, 3 Oktober 2016.

Bawani, Imam Pengantar Ilmu Jiwa

Perkembangan, (Surabaya: Bina Ilmu, 1985.

Hafidzi, Anwar. "Dampak Dari Penetapan UU Nomor 26 Tahun 2000

Terhadap Kejahatan Kemanusiaan Dan Genosida Di Indonesia." Syariah Jurnal Hukum Dan Pemikiran 15, no. 2 (2016).

"Eksistensi Advokat Sebagai Profesi Terhormat (Officium Nobile) Dalam Sistem Negara Hukum Di Indonesia." Khazanah: Jurnal Studi Islam Dan Humaniora 13, no. 1 (2015).

. "Prasyarat Poligami Dalam Kitab Fiqih Islam Dan Kompilasi Hukum Islam Perspektif Maslahah Mursalah." Al-Daulah: Jurnal Hukum Dan Perundangan Islam 7, no. 2 (2018): 366-392.

Hafidzi, Anwar, and Safruddin Safruddin. "KONSEP HUKUM TENTANG RADHA'AH

DALAM

PENENTUAN NASAB."

Khazanab: Jurnal Studi Islam Dan Humaniora 13, no. 2 (2017): 283317.

Hanafi, Ahmad, Asas-asas Hukum Pidana Islam, Jakarta: Bulan Bintang, 1986.

Ibrahim Muhammad Jamal, Fiqih Wanita, Alihbahasa Anshari Umar, Semarang: Asy-Syifa, 1989.

Majelis Ulama Indonesia (MUI), Ajaran

Islam dan Penanggulangan Perkawinan

Usia Muda, Jakarta: MUI dan

UNICEF, 1991).

Mardham al-Imam, Agama Yang Lurus

Benar, (Jakarta: Kalam Mulia, 1999).
Perkawinan Usia Dini”, Banjarmasin

Post, 16 Desember 2017.

Radja, Aditia Maruli, "Heboh Kasus Syekh Puji”, Antara News, Semarang 22 Desember 2008.

Said, Muhammad, Ilmu Pendidikan, Bandung: Alumni, 1985.

Sayyid Sabiq, 1987. Fikih Sunnah 9, Alih bahasa Moh. Nabhan Husein, Bandung: Almaarif, 1987.

Soesilo, R., Kitab Undang-undang Hukum Pidana serta Komentar-koemntarnya Lengkap Pasal Demi Pasal, Bogor: Politeia, 1991.

Undang-Undang Peradilan Anak, Jakarta: Sinar Grafika, 2000.

Undang-Undang Perkawinan UU Nomor 1 Tahun 1974, 2000. Surabaya: Pustaka Tintamas.

Undang-Undang RI Nomor 3 Tahun 1997 tentang Pengadilan Anak, 2000. Jakarta: Sinar Grafika.

Zuhdi, Masyfuk, Masail Fiqhiyah, Jakarta: Haji Masagung, 1996. 